Chapter Title: Visual Media and the Healthy Self in the 20th Century: An Introduction Chapter Author(s): Christian Bonah and Anja Laukötter

Book Title: Body, Capital, and Screens

Book Subtitle: Visual Media and the Healthy Self in the 20th Century

Book Editor(s): Christian Bonah, Anja Laukötter

Published by: Amsterdam University Press. (2020)

Stable URL: https://www.jstor.org/stable/j.ctv12sdvgj.4

JSTOR is a not-for-profit service that helps scholars, researchers, and students discover, use, and build upon a wide range of content in a trusted digital archive. We use information technology and tools to increase productivity and facilitate new forms of scholarship. For more information about JSTOR, please contact support@jstor.org.

Your use of the JSTOR archive indicates your acceptance of the Terms \& Conditions of Use, available at https://about.jstor.org/terms

This book is licensed under a Creative Commons Attribution-NonCommercialNoDerivatives 4.0 International License (CC BY-NC-ND 4.0). To view a copy of this license, visit https://creativecommons.org/licenses/by-nc-nd/4.0/. access to Body, Capital, and Screens 


\title{
Visual Media and the Healthy Self in the 2oth Century: An Introduction
}

\author{
Christian Bonah and Anja Laukötter
}

\begin{abstract}
To introduce Body, Capital, and Screens as a series of in-depth case studies at the intersection of film and media studies and the social and cultural history of the body, we have chosen, as with all of the contributions, a film emblematic for the chapter's specific thematic focus: Victoire de la vie/Victory of life (FR, 1937) by Henri Cartier-Bresson. Through these images, we intend to detail our approach illustrating how the material and social aspects of moving images have served as a hyphen between body politics, on the one hand, and the market as the zoth century's primary form of social and economic organization, on the other. We lay out the framework for connecting bodies and capital with the significance of a century's worth of utility media culture.
\end{abstract}

Keywords: health, capital, Cartier-Bresson, Victoire de la vie/Victory of life, Spanish Civil War, children, documentary impulse, media, film

Body, Capital, and Screens: Visual Media and the Healthy Self in the 2oth Century is about how the material and social aspects of moving images have served as a link between body politics, on the one hand, and the market as the 2oth century's primary form of social and economic organization, on the other. The book is the product of work undertaken by the international research group 'The healthy self as body capital: Individuals, market-based societies, body politics and visual media in the twentieth century Europe.'

1 This project has received funding from the European Research Council (ERC) under the European Union's Horizon 2020 research and innovation programme (grant agreement No. 694817), https://bodycapital.unistra.fr, accessed 19 September 2018.

Bonah, C. and A. Laukötter (eds.), Body, Capital, and Screens: Visual Media and the Healthy Self in the 2oth Century. Amsterdam: Amsterdam University Press, 2020 DOI 10.5117/9789462988293_INTRO 
The group's historiographical research, carried out with a cultural-studies bent, focusses on visual media (ranging from documentary and amateur film to television and the internet) and the body and their relation to a variety of health issues. In turn, the group seeks to connect this visual history of the body with economic history. ${ }^{2}$

We conceive visual media not merely as a mirror or expression of the things they depict, but as media and art endowed with their own distinct, interactive, performative power. Furthermore, we think that studying them is essential for a number of reasons: because their distribution has grown considerably over the past century; because they transcend spatial boundaries, whether they be those of nations, social groups, or professional associations; because their utilitarian character and their use as tools of promotion and communication links them to market-economic principles. Visual media are, for us, a vantage point. They have produced a form of knowledge and scientific objectivity with and without words, 3 transforming word-based health politics by channelling it into an increasing variety of visual communications media. This has ultimately proven essential for the enactment of beliefs about health and body practices in the communication societies of the 2 oth century.

Our approach is distinct from a history of bodies on screens (film history) and a body history with moving images (history of representations). Instead, our goal has been to write, through the cipher of visual sources, a history of the interaction between bodies and visual media, both on-screen and off-screen. By placing primacy on the 'through', our analysis positions moving images as our starting point. We treat moving images as a corpus of sources, analysing their language, context, and interdependencies with their contents. Finally, our approach takes visual media as a historical source that can complement-and sometimes serve as an alternative to-written sources. They can also serve as counter-archives to dominant state-organized visual sources, ${ }^{4}$ recording what the Magnum Photo Agency characterized as the pulse of a time. In short, visual material might be seen as the 2oth century's paramount archival source. ${ }^{5}$

The authors have chosen to work with the concept of 'body capital' in order to open space for a new perspective on economically grounded health practices that is founded in a rigorous, inductive analysis of visual 
culture. Just as the engine was a key metaphor in depictions of the body in films and written sources from the first half of the 20 th century, ${ }^{6}$ the body conceived as capital became a leading visual and non-visual metaphor at its end. As a form of capital, the body has been treated as a means of production, a source of value to be protected, managed, and harvested, a source of value constantly at risk, a value that promises future returns. But our use of body capital is not metaphorical. It stems from the economic concept of capital and its use in sociological criticism. On the one hand, the concept confronts the reality of the prevalent use of 'human capital', defined as embedding resources in people. ${ }^{7}$ On the other, it draws on Pierre Bourdieu's notions of cultural or social capital, which he developed to explain social inequalities and domination as consequences of economic capitalization. ${ }^{8}$ As we will outline later, body capital provides a framework for studying the interdependencies between bodies, screens, and markets. This framework opens a new perspective on questions about the commodification of bodies and the marketization of health, ${ }^{9}$ about the links between health and aesthetic appearance, and, most importantly, about the increasing imperative to measure and make measurable bodies and capital. ${ }^{10}$

As a heuristic concept, body capital should not be seen as another bead on the already long string of body-related capitals, such as health

6 Rabinbach, Human Motor.

7 Becker, 'Investment in Human Capital'.

8 Bourdieu and Passeron, La reproduction; Bourdieu, Esquisse d'une théorie; Bourdieu, 'Les trois états'; Bourdieu, 'Forms of Capital'.

9 Commodification is used here in a wide sense, beyond commodification of body parts in organ transplants; Scheper-Hughes and Wacquant, Commodifying Bodies. We are referring to processes of transforming health practices and behaviours into sanitary objects and goods. For example, for cleanliness, there is hypoallergenic soap; for tuberculosis prevention, there is proper nutrition, vitamin supplements, and Bacillus Calmette-Guérin (BCG) vaccines; for obesity, there are anti-obesity drugs, etc. Health products, of course, cover the most visible preventive and therapeutic agents/medicines-from vitamin D pills replacing exposure to sunlight, vitamin supplements complementing fresh fruit, or lifestyle drugs such as Viagra - but they also cover an increasingly diverse array of self-monitoring devices-from thermometers and scales to blood sugar or hypertension monitors, fitness watches, and sleep monitors -increasingly tracking and measuring our lives and quantifying ourselves. Greene et al., Therapeutic Revolutions.

10 Measurement and measurement devices are core values and tools in 2oth-century economics and biomedicine, helping ensure that people make decisions in an allegedly rational manner. They deal with individuals as discrete units. They are localized and determined. They also have a temporal component where investments link the present to future outcomes. Capital is a bridge between now and the future. Grossman, 'On the Concept'. 
capital, ${ }^{11}$ emotional capital, ${ }^{12}$ symbolic capital, ${ }^{13}$ psychological capital, ${ }^{14}$ mental capital, ${ }^{15}$ or erotic capital. ${ }^{16}$ The analytical concept of body capital, in contrast, combines the economic notion of a resource that enables the production of more resources with the sociological notion of symbolic capital that produces the social in terms of accumulation, objectivation, instrumentalization, and interiorization. Most important for our research is the analytical horizon opened by the concept of body capital, which enables us to trace the interconnections between visual media-long conceived of

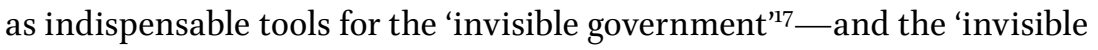
hand' of the market. Many of the chapters in this book seek to detail this interconnection beyond the more self-evident relations between promotion, advertisement, and corporate public relations. ${ }^{18}$

Our work begins with images. Visual media provide not only the primary material of the book, but also give it its organizational principle. Each article begins with an analysis of a film, this introduction being no exception. Our choice for the introduction is photographer Henri Cartier-Bresson's film Victoire de la vie ('Victory of life', 1937).

The first images of the documentary sound film show children in the streets, a toddler, a woman walking by observing girls playing and jumping, and a group of older boys working, cleaning the street (Figure o.1). The scene is Madrid: a long panning shot down a central street of the Spanish capital shows us crowded sidewalk markets and queues in front of shops. A voice from the off comments: 'Madrid continues to live under the spell of bombing. ${ }^{19}$ Cut. A soldier filmed from the back slowly patrolling the empty streets. A group of children on the ground in a circle. A passage between two defence walls with gun shafts. Off-voice: 'The war zone where no one lives. ${ }^{20}$ The camera then moves into a dark area beyond the walls, then a cut to scenes of destruction. Then there is a shot of a cameraman filming a soldier seated on a chair among the ruins. The streets are blocked off by barricades, with uneasy citizens moving haltingly through them.

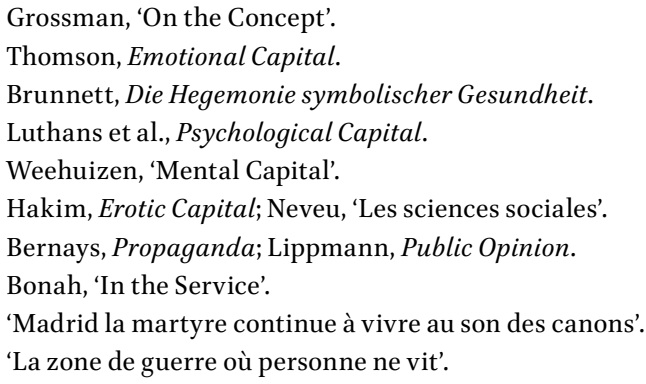



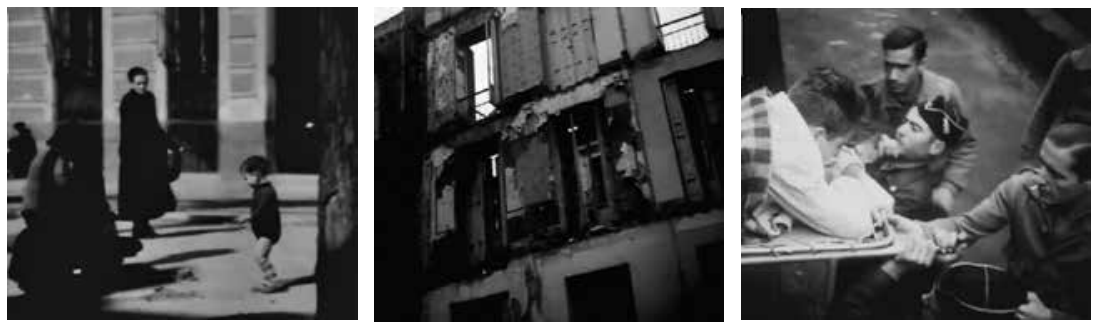

0.1. Three stills from Victoire de la vie ('Victory of life', 1937).

Wide-angle shots from below document the destruction of houses and churches, magnifying the devastation of living conditions. These images of a war zone are presented as the effects of military conflict. This thematic framework is not only established by images of children and the camera's focus on their bodies, but also by informative tables and animation that explain the situation. Images of sanatoria and dispensaries follow before we see factories manufacturing sanitary products. Cartier-Bresson then films the training of stretcher-bearers and shows the departure of soldiers and life on the front. The camera follows the movement of mobile hospitals. Images of care are underlined with shots of wounded, but nevertheless rescued soldiers. We see images of the hospitals like the Murcia, a military hospital in Barcelona, and images of the well-known Ritz Hotel, which was used as a hospital during the war. After showing their exterior, Cartier-Bresson then takes us inside to see how they care for their patients, the arrangement of the hospital, doctors performing surgery, and wounded people lying in wait. Various animations describe the Barcelona hospital's services before asking viewers for donations. This request is followed by images of amputees struggling to adapt to a life without legs. At the Spanish border Puigcerda, we see refugee children playing and dancing. At the convalescent centre in the city of Benicassim near Valencia, we see images of the wounded and their rehabilitation before we see how men leave for battle.

Victoire de la vie was created by the French photographer, artist, and director Henri Cartier-Bresson, who, in 1937, decided to travel with his camera team throughout Spain to shoot a documentary on the work being done by the American medical unit American Medical Bureau in the Spanish Civil War. He produced it for Frontier Films, an organization born out of Nykino, a militant cooperative of film-makers based in New York. ${ }^{21}$ Debates within the $1930 \mathrm{~s}$

21 The film is credited to Henri Cartier. Cartier-Bresson's political communist engagement between 1936 and 1946 and his militant utility film-making with Ciné-Liberté after an experience as Renoir's assistant for the 1936 election communist campaigning film La vie est à nous was 
French left on the 'new culture' provide context for Henri Cartier-Bresson's film, and can help us understand why militant organizations, political groups, and trade unions produced films like Victoire de la vie in the times of the Popular Front. ${ }^{22}$ Jean-Richard Bloch, an influential representative of the 'new culture' movement, published several texts encouraging the left to integrate new media into their work in order to escape the constraints of traditional literary culture. ${ }^{23}$ The awareness that radio, photography, and film were vital forms of expression and communication was quite widespread at that time. But, before 1935, leftist organizations did not have the means necessary to produce anything of real force. This situation changed in the spring of 1936 , when a series of strikes triggered an influx of membership that brought new funds to parties and organizations. The union movement was so massive that, in the span of a month, the majority of film technicians had become union members, almost from zero. This allowed organizations sympathetic to the leftist cause to invest in production. ${ }^{24}$ Many of the technologies and forms of moving images and the different types of screens analysed in this book correspond to Bloch's sense of novelty. ${ }^{25}$ Mass communication, cutting-edge artistic forms, and technological novelty remained an enduring promise of moving images everywhere. In short, the moving images literally had, or were at least attributed with, the power to move things.

As a French Popular Front film, internationalist and pacifist in its message, Victoire de la vie was part of a broader movement of social documentation in film that included the Farm Administration films in the United States

concealed in order not to compromise his entry into the United States immediately after the Second World War. Assouline, Henri Cartier-Bresson.

22 Among the militant organizations, some of the most important include the films produced by the French Section of the Workers' International (SFIO), the General Confederation of Labour (CGT), and the French Communist Party (PCF) with Humanity. From May 1935 until early 1937, the SFIO was the most systematic producer of films under the impetus of Marceau Pivert, one of the few politicians really interested in cinema. The film service of the Socialist Federation of the Seine produced, in all, about fifteen pieces of 'proletarian counter-news'. Ory, La Belle Illusion.

23 Ory, La Belle Illusion.

24 The militant cinema of the Popular Front sought to associate films of a new spirit (social, union, popular) with a new style of producing. From this point of view, the Front's emblematic film remains Jean Renoir's La Marseillaise, an unfinished but remarkable 1937 attempt at a cooperative production financed by viewers.

25 Here, one can identify three kinds of modernity: 'modernism' as a supranational artistic filmic avant-garde; 'modernization', engaging bodily practices in connection with industrial production processes; and 'modernity' as a particular mode of historical life associated with patterns of consumption and advertising. The distinction is borrowed and adapted from: Elsaesser, 'Propagating Modernity', p. 236. 
and the Empire Marketing Board films in the United Kingdom. These films mixed information and education with counterviews in order to unveil political manipulation and hegemonies, and, at the same time, to shape perceptions and orientate behaviours.

The film Victoire de la vie captures the book's thematic scope and form well. This volume focusses on visual media that informed and educated people about life and health and improving health practices, a strong example being Cartier-Bresson's documentary film. At the centre of our investigations are visual (mass) media, useful/utility film and inédits (amateur, family, and private visual media), and television. We are interested in forms of documentary depiction of bodily realities. Related visual materials, such as mainstream films or still images like posters or exhibitions, will only be considered insofar as they are immediately relevant to the production and reception of documentary film. Our central interest, in other words, is not the Hollywood/Pathé-style fictional portrayal of health, body, and illness. ${ }^{26}$

Carefully directed by Henri Cartier-Bresson, Victoire de la vie was produced to support Republican Spain and make known the activities of the Centrale Sanitaire Internationale in order to obtain moral and financial support. To this end, he shows the health efforts and mobilization of Republican Spain, on the front lines and behind the scenes, and the medical solidarity of foreign countries coordinated by the International Health Centre (CSI). Films like Victoire de la vie that document the world and at the same time try to change it were produced in abundance during the 2oth century. Studying their visual characteristics lies at the heart of this book. The scope of the book, however, sweeps wider. The authors seek to demonstrate that visual media played a constitutive role in the cultural history of the body in the 2oth century and to detail some of the ways in which mass media have helped shape and influence our bodily conditions and our self-awareness or understanding of them.

\section{Body Capital}

The core idea of the book is, to a great extent, inspired by Pierre Bourdieu's influential sociological work Distinction: A Social Critique of the Judgement of Taste. ${ }^{27}$ Bourdieu identifies economic, social, and cultural capital as forces

26 Harper and Moor, Signs of Life; Reagan et al., Medicine’s Moving Pictures; Friedman, Cultural Sutures.

27 Bourdieu, La distinction; Bourdieu, Esquisse d'une théorie; Bourdieu and Passeron, La reproduction; Bourdieu, 'Forms of Capital'. 
in order to describe individuals' positions in (French) societies. Going one step further, we argue that understanding the increasingly marketized world of the 2oth century demands supplementing this tripartite conception of capital with a fourth term. The concept of body capital introduced in this book is founded on the conviction that the (healthy) body has evolved into a new (fourth) currency. Succinctly put, it denotes an individual resource that can be nurtured and then mobilized, invested in and employed for future returns.

There are at least two compelling reasons for conceiving of the body as a new 'capital form'. One is that the concept of body capital allows us to stress the economic aspects of individual health in the 2 oth century. In the nineteenth and in beginning of the 2oth century, state-run health programmes were primarily concerned with the useful and functioning body understood as a collective body. Over the run of the century, however, this focus shifted to place more emphasis on individual health and the promotion of practices of self-optimization. Supported by new health products in caring for themselves, individuals are able to bargain with their body capital in different social spheres. Perhaps more importantly, however, individuals have internalized health practices to such an extent that they create new subjectivities. An example of the significance of health in job markets in Western countries like Germany and France is that discrimination for being overweight can sometimes be just as strong as racial discrimination. The fit and slim body is recognized as an expression of self-discipline and high potential, while the overweight body is regarded as a marker of negatively connoted loss of control. ${ }^{28}$ Thus, one could argue that it is not an option or a freedom to live a healthy life, but an imperative. The self-optimized individual, as Michel Foucault has described it, has become a key political tool of the liberal or capitalist system. ${ }^{29}$ Over the last decade, the burgeoning field of the history of capital and capitalism has produced several path-breaking works on the processes, mechanisms, and effects of capitalism (including in health systems) on a micro and macro level in Western societies. ${ }^{30}$ Yet, beyond a few select works, the role of visual media has largely been neglected in the extant literature. ${ }^{31}$ It seems that visual media are primarily viewed as part of the cultural sphere, disconnected from issues of economics. This book

\footnotetext{
28 Jay Rowell, comment on the workshop Capital and Capitalism in Strasbourg 2017.

29 Foucault, Le gouvernement de soi.

30 See, for example, Illouz, Cold Intimacies; Budde, Kapitalismus; Kocka and Linden, Capitalism; Bänziger and Suter, Histories of Productivity; Donauer, 'Emotions at Work'; Ebbinghaus and Manow, Comparing Welfare Capitalism; Lengwiler and Madarász, Das präventive Selbst.

31 Berridge and Loughlin, Medicine.
} 
cannot fill the gap with one fell stroke, but it might accomplish the more modest goal of encouraging further research in this direction. The concept of body capital was coined to bridge these spheres and to help analyse their interconnections and even interdependencies. Thus, the book aims to understand better the role that modern visual mass media have played in the shift in health paradigms over the span of two centuries. Dominant at the beginning of the 2oth century was a national, biopolitical publichealth paradigm characterized by collective bodies, workforce, and labour society. By the late 2oth century, the paradigm shifted, as market forces and market fundamentalism increasingly came to determine the norms of what constitutes a better, healthier individual life. Visual media, as the book tries to show, not only reflect this historical process and development, but have, to a large extent, shaped it. In the 199os, scholars like Lisa Cartwright undertook important theoretical reflections on film in the sciences, work that has recently been given a new life by scholars like Oliver Gaycken and Scott Curtis. ${ }^{32}$ Still, theoretical work on the documentary depictions of body realities remains rare. ${ }^{33}$ Our book addresses this research gap.

Second, the concept of body capital allows us to stress the high value attributed to the body in the 2oth century. This is not to say that Pierre Bourdieu leaves out the body in his analysis of capital or in his overall theory. To the contrary, his key concepts all have a strong corporeal dimension, whether it be 'habitus' as a product and producer of practices, 'hexis' as a system of attitudes and movements, or, especially, the concept of 'incorporation' as the assimilation of structures and practices. ${ }^{34}$ Without specifically focussing on the body, these theoretical frameworks clearly underline that the individual body is defined by economic, social, and cultural capital. These forms of capital motivate us to create knowledge on how to dress, move, and eat in different social settings. Perhaps more importantly, it is through them that our bodies are both defined and can redefine social structures and classes.

So, what does body capital do for us? As Christiane Reinecke has rightly argued, Bourdieu's theoretical framework and his empirical research for Distinction have to be understood in the context of French society in the $1960 s$. To a certain degree, Bourdieu misses the gradual dissolution of class structures, the processes of individualization and globalization, and the relevance of gender, race, sexuality, and age in the 20 th century. ${ }^{35}$ We would

Cartwright, Screening the Body.

Gaycken, Devices of Curiosity; Curtis, Shape of Spectatorship.

See Bourdieu, 'Zur Genese'; Bourdieu and Wacquant, Réponses; Fröhlich, 'Habitus und Hexis'. Reinecke, 'Der (damalige) Geschmack'. 
add the analytical category of the body to Reinecke's list. Even though Bourdieu had a clear notion of the relevance of the body, he generally placed it in the background. To bring the body out of the shadows and underline its increasing importance in the long run of the 2oth century, we single it out and work with the concept of body capital.

The transformation of the body into a form of capital, at least on a conceptual level, has a strongly corporeal dimension. ${ }^{36}$ It brings in and combines, as Andreas Reckwitz has put it, the 'cultural and the material, the symbolic and the objective'. ${ }^{37}$ Moreover, the focus on the body makes it possible to consider affects and emotions, two phenomena largely neglected by Bourdieu.$^{38}$ As historian and anthropologist Monique Scheer-who draws on Bourdieu's concept of 'habitus' - has argued, the body has a strong historical dimension and is linked to embodied emotion practices. ${ }^{39}$ Important for our work are the social and communicative aspects of emotions, which play a crucial role in the persuasiveness of media productions. ${ }^{40}$ In this sense, the book aims to highlight theoretically and empirically the interactive force and performative power of films on subjects in the modern world: how these films worked to influence behaviours and attitudes towards one's own health and one's body, and how health became a form of investment for the future, one of the meanings of capital.

This is also the way we analyse Victoire de la vie. The film opens with a three- or four-year-old boy entering the frame from the right. The camera follows his movement in a panoramic shot, he looks briefly into the camera, and the boy then hesitantly turns to a sand pile in the grey street. At the same time, a woman enters the frame from the opposite side, observes him briefly, and passes by. A girl plays on the dirty sidewalk with a bucket. A group of children plays a jumping game on the sidewalk. In March 1937, Cartier-Bresson had shot a series of 31 photographs for the communist newspaper $\mathrm{Ce}$ Soir; this series was published on the front page. Produced in the context of a photo contest, the photo series 'The Lost Child' portrays children's misery. Henri Cartier-Bresson presents the children as in need: They are depicted playing simple games on the streets, chatting, dancing outside, and generally enjoying themselves as 'normal' children without paying attention to their desperate surroundings. These children are

Reckwitz, 'Practices and their Affects', p. 115; Reckwitz, 'Habitus oder Subjektivierung?', p. 59 .

38 Reckwitz, 'Practices and their Affects', p. 116.

39 Scheer, 'Are Emotions'. See also Eitler and Scheer, 'Emotionengeschichte als Körpergeschichte'.

40 Laukötter, 'Politik im Kino'. 
representations of innocence. They are supported, helped, and educated by adults who clearly underline how happy they are to care for the children and enable them to live healthy lives. In that sense, these children are not only innocent but also the representation of the future of Spain. In reference to the film title, the children are the victory of life, icons and incarnations of what the bombs and the enemy has not — cannot—destroy. Against the backdrop of war and misery and severely wounded soldiers, these innocent children, with their healthy bodies, are the capital of a nearby and hopefully better and more secure future.

Both produced in and derived from visual media, body capital is a distinctive power and an economic currency. This provides the framework for the case studies in this volume. The case studies analyse the various interests, motivations, and practices of a range of various global, national, and local health institutions, different industries (media industries, pharmaceutical industries, health supplies industries, etc.), sciences (medicine, psychology, etc.), classes, specific interest groups (like self-help and activist groups), and, last but not least, visual media commissioned by both the state and private corporations.

\section{Perspectives on Time and Spaces (and Their Hierarchies)}

Much of what non-fiction television and other visual media produced in the 2oth century was influenced by what Gregg Mitman has described as the century's 'documentary impulse', which was informed by the belief in the capacity of photographs and films to 'visually capture the world, order it, and render it useful for future generations'. ${ }^{41}$ As we are concerned with the long-term efficacy of the production of images over the past century, our book explores utility and educational films, ${ }^{42}$ television, ${ }^{43}$ and amateur film/video. ${ }^{44}$

41 Mitman and Wilder, 'Introduction', p. 1.

42 Ostherr, Medical Visions; Acland and Wasson, Useful Cinema; Orgeron et al., Learning; Bonah et al., Health Education Films; Zimmermann, Geschichte; Hediger and Vonderau, Films that Work; Hediger et al., Films That Work Harder; Zimmermann, Schaufenster Schweiz.

43 Boon, 'Medical Films and Television'; Boon, Films of Fact; Bourdon, Histoire de la télévision; Delavaud and Maréchal, Télévision; Lafon, Histoire de la télévision régionale; Lévy, Regards de la télévision française; Poels, Les trente glorieuses; Sauvage and Veyrat-Masson, Histoire de la télévision française; Powell and Shandley, German Television; Gumbert, Envisioning Socialism; Soulages, Les rhétoriques télévisuelles.

44 Mattl et al., Abenteuer Alltag; Forster, 'Mitten hinein'; Odin, Le film de famille; Zimmermann, Reel Families. 
Spanning three major media ages (film, TV, internet), we seek not to disregard their differences, but instead to focus on long-enduring structural elements. In this sense, our project might be seen as a longue durée contextualized media archaeology. Yet, while taking these differences and the historical development of each media into account, the book argues that there are also a variety of overlaps and mutual influences between these distinct media forms that pertain to their themes, formats, aesthetics, etc. 45

Our comprehensive approach, which is anchored in our research on documentary films, is not an end in itself. On the contrary, including all different media seems necessary for developing an accurate understanding of how moving images displayed, impacted, transformed, produced, and represented bodies in the 2oth century. Only by analysing and comparing various media formats is it possible to gain a well-rounded perspective on how the body became a medium and a site of embodied 'capital'. Studying issues of health in visual media over a longer time period, we intend to trace the above-mentioned shift in health policy and campaigns from the early 20 th century to the present. While the former was dominated by a paternalistic state, with religious, political, or professional prescriptions mapping out 'ways to strength and beauty' (according to the UFA film, Wege zu Kraft und Schönheit 1924/1925), the latter moved towards a mode of governing bodies wholly justified on economic grounds, which, at least in theory, has, as its highest aim, the expansion of individual consumer choice. A longue durée approach on the visual material studied seems especially necessary if we take the massive changes in health systems and understandings of health and diseases throughout the 2oth century into account.

The changes were immense: at the beginning of the century stood the invention of public health, the rapid emergence and diffusion of mechanically produced images and moving pictures, and a revolution in liberal economic theory and practice. By the end of the century, there was the reinvention of new public health, the internet revolution, and the economic crisis that gave birth to economic neoliberalism in the 1990s and 2000s. In the middle of this period, and central to our book, lie the industry-based therapeutic revolution and medicalization of society, the invention of television, the epidemiological transition (increased life expectancy and the emergence of chronic disease), and the golden age of the welfare state. All of this exerted a decisive and lasting influence on body practices and perceptions.

We start our book with the film Victoire de la vie. It is a militant film produced in the heyday of state propaganda before the Second World War

Hagener et al., State of Post-Cinema; Strauven, Cinema of Attractions Reloaded. 
by a leading photojournalist and founder of the Magnum Photo cooperative picture agency. Thereby, and more generally throughout this book, we aim to dislocate and reframe classical boundaries of media studies - photography, film, TV, and internet - and of established historic periods-First World War, interwar period, Second World War, Cold War, etc. In doing so, we seek to uncover continuities in audiovisual and mass-media culture where classical historical accounts and disciplinary boundaries frequently suggest breaking points.

In this sense, Cartier-Bresson's Victoire de la vie exemplifies what is at stake. The first half of the century was dominated by the world wars. Accordingly, much of the political, economic, and social activity of this period was determined by military conflict, its causes, and its consequences. As Victoire de la vie shows, this can neither be restricted to the two world wars, nor to individual belligerent countries. What is evident from film archives is that military conflicts and preparation for them were forceful catalysts for audiovisual production and mobilization.

Visual media shaped the 2 oth century in significant ways. Interestingly, although many films - a point particularly pertinent as concerns their relationship to the body-were produced for specific spaces, they often ended up being received outside of these spaces. The term 'space' has a variety of meanings. One might think of professional spaces (as, for example, the laboratory, the clinic, industry, the pharmaceutical industries), social spaces (like schools, homes, activist groups, etc.), and even national and global spaces. Moreover, screening spaces vary, from large screens in cinemas, clubs, or civic spaces, whether they be indoors or outdoors; small screens in homes, schools, or public television sets; and other screens like computers, smartphones, and similar devices. The accessibility of these various types of screens is part of the production and reproduction of social hierarchies. Not all of these spaces and screens can be addressed in this book, but we have nevertheless sought to discuss a variety.

In her chapter on United Nations Educational, Scientific and Cultural Organization (UNESCO)-sponsored films in the 1940s and early 1950s, Zoë Druick elucidates how the spirit of transcending national boundaries has historically guided international approaches to film production. Envisioned to have a global reach, these films tried to educate people about peace, freedom, and cosmopolitan world citizenship. This chapter argues that these goals did, by no means, escape reinforcing hierarchies and making normative judgements: in combining reportage, documentary, and moral injunction, these films undermined not only the biopolitical orientation of the United Nations (UN), but also its supremacy in the Western world. 
Moreover, she argues that, even though UNESCO's universalism aimed to debunk 'race' as a category in their official statements, it was perpetuated in their media text and production.

The decentring of the Western perspective is taken further in Jean-Paul Gaudillière's contribution. Entering the debate on the production and reproduction of political and social hierarchies in visual media, his chapter analyses aspects of the north-south divide in film. It offers an account of discourses on body government, drawing on recent subaltern and world historiography of health outside Europe. Gaudillière's study begins by critiquing several films about the Global South that were produced by Western institutions and thus reproduce their viewpoints and biases. After pointing out these films' problematic aspects, Gaudillière proceeds to make a plea that scholars consider alternative visual records that originated in the Global South and argues for the need to provincialize Europe and North America. In this sense, the chapter poses a challenge both to Gaudillière's own selection of films as well as to the book as a whole, as the majority of films studied in this collection come from the West (Germany/GDR, Great Britain, France, United States).

But hierarchies with a highly normative dimension were propagated not only through transnational visual media productions, but also within national borders, as Olaf Stieglitz clearly shows. In his chapter on the expanding markets for participatory sports in the United States between the 1890 s and the 1930s, he analyses how visual media like film and photography were integrated into the creation of normatively idealized bodies. The images of swimming helped introduce a scientific understanding of bodies and their motions to a broader audience. Moreover, these swimming bodies served as sites where the body as a modern, ubiquitous, and attractive, sexualized, marketable commodity was negotiated. Moreover, Stieglitz shows how these visual media addressed issues of gender, race, ethnicity, and age.

The next two chapters highlight voices of dissent. Christian Bonah's chapter on sex education in French National Television around 1968 begins with an account of how mainstream television (after having become a mass media in France) and various prominent people believed that the 'invasion' of erotic depictions of the female body was a visual translation of the so-called sexual revolution. ${ }^{46}$ Bonah shows that, while state-produced films and TV broadcasts can serve historians as a primary source, they should not be seen as the final statement on particular historical phenomena. Other

46 L'invasion de la sexualité dans la vie quotidienne, ORTF, 25 January 1971, 01:02:07, INA MediaPro database identification number CAF93024168. 
audiovisual sources can be used as counter-archives to explore different framings of the same phenomena and the different aspects of history that they reveal. ${ }^{47}$ From school television and pioneering experimental forms of participative television production to militant video productions, the counter-archives provide examples of marginal or subversive approaches, both in terms of the stakeholders involved and the content they showed. These subaltern sources reveal a series of attempts to put on film ordinary talk about sexuality, which were influenced by new developments in camera technology and the technique of direct cinema.

Sophie Delpeux's contribution analyses how Austrian artist VALIE EXPORT's video and body art of the late 1960s destabilized bourgeois understandings of the body and capitalist appropriations of art and media. This study on the artist's pastiches made of advertisements reveals a biting criticism of a male-engineered and male-dominated social reality. In this criticism, EXPORT makes clear that body capital is constructed by the male gaze. In contemporary art as a market, the value resides with what the artist embodies more so than what they produce or do. What EXPORT creates is a reverse form of body capital, where the artist's body as capital becomes a critique of economic capital and capitalization. Delpeux elucidates well Baudrillard's claim that the 'emancipation of woman and the emancipation of the body are logically and historically linked', at least in the Western traditions and hierarchies. ${ }^{48}$

\section{Screens and Markets/Capital}

Victoire de la vie is a typical non-fiction film, one of thousands produced in Europe and North America between the First and Second World Wars that straddle the line between documentary and propaganda and were produced to promote, educate, or agitate around a particular issue. ${ }^{49}$ As engaged films with a message, these visual media intend to make the viewer realize or do things. They are performative in intent. This is one of our major concerns, hypotheses, and claims: Beyond their capacity to represent, films intervene, influence, co-produce, and may even condition the content that they document. We argue that moving images throughout the 2oth century have participated in shaping the way we live and the world we live in. We 
consider them as an active force, not only as something that reveals or portrays. The question is then: What do these films do to make people do things (or fail to make them do)?

Cartier-Bresson's film is concerned with mobilizing international solidarity and funds for a cause. It demonstrates more generally that screens can serve as stages for public agendas, going beyond being mere surfaces of projection. Films that seek to promote a humanitarian mission or political solidarity, however, were not only a phenomenon of the social and political conflicts of the 1930s. They have a long history that includes the early volunteer society films of the 1920 and, after the Second World War, films produced by the American Cancer Society, the Association Française contre les Myopathies, and similar patient associations/charity organizations in the Western world. ${ }^{5^{0}}$

Beginning in the 196os, television brought forth the telethon, a form of fundraising entertainment geared towards mobilizing audience compassion. One such example is addressed in more detail in the chapter by Karen Lury on the BBC's Children in Need telethon, a television broadcast that has been running for over 35 years. Lury's analysis connects how televisual grammar conceived as currency aligns with currency models within the economy of the National Health Service (NHS).

Viewed as a 'proletarian counter newsreel', Victoire de la vie needs to be read in connection with 1930 s propaganda documentaries' practical aspects of informing, instructing, and indoctrinating. From the marching military music that introduces the first (dissonant) images of children playing, to the long sequences of the care of wounded soldiers reminiscent of post-First World War cripple films, Cartier-Bresson subverts these images to project his plea for international solidarity. In this sense, he aims at a 'visual (counter) construction of the social'. ${ }^{11}$ But does this function in the way the director (or the group that commissioned the film) intended? And, if so, how? We have little information about where and how Victoire de la vie was screened and if it actually mobilized people as hoped. Questions about reception are essential and they surface early on in the history of utility films, as Anja Laukötter has shown elsewhere..$^{2}$ These questions are as important for producers as they are for historians, helping us not to misperceive the significance of a film or simply equate aesthetic quality with reception performance. Since early studies on the reception of health films conducted

$5^{0}$ Rabeharisoa and Callon, Le pouvoir des malades.

$5^{1}$ Mitchell, What Do Pictures Want?; Mitchell, 'What Do Pictures Really Want?'; Mitchell, Picture Theory.

$5^{2}$ Laukötter, 'Measuring Knowledge and Emotions'; Laukötter, 'Politik im Kino'. 
in the 1920s, however, the issue of evaluating and measuring the performance and effectiveness of films has posed considerable difficulties. ${ }^{53}$

Luc Berlivet addresses this issue in his analysis of anti-alcohol health campaigns in France in the 1980s, which were part of new public-health strategies directly linked to booming advertisement agencies and practices. In the golden years of evidence-based medicine, health advertisements were informed by policy studies and field experiments in social psychology. In the same period, audience studies became an integral part of television programming, and, in telling fashion, telethons integrated a form of efficiency measure into their very format. At the centre of the set and programme was, and still is, the donation counter that tallies up the money raised, as Karen Lury's article on telethons analyses. Screen efficacy was simply translated into money. Measurement was immediate and integrated into the show, thus illustrating how the measurement directly influenced that which was being measured. At the same time, producers planned 'money shots', a term used to describe visual sequences they knew would trigger donations.

War is present throughout Victoire de la vie. It is not illustrated by explicit images of combat or bombardments, but rather through implicit images of destroyed churches and religious objects. War is mainly observed from latent scenes, not through war scenes, but in the documentation of destruction as a consequence of belligerence. Nevertheless, the film does take a political position. In order to remind the viewer of how the 'Army of Africa' and Nazi Germany supported Franco's troops, the director uses a simple shot filmed inside a fortified shelter taken over by the Republicans: One sees a swastika and the badge of the 'Army of Africa'. Moreover, Cartier-Bresson's depiction of Spanish men also has political implications: Shots show a soldier learning to read, wounded patients playing chess, a sequence taking place in the countryside where farmers give half of their harvest to the army (some of them even make a fist as a symbol supporting the army's efforts). Furthermore, in the film's last sequence, the militiamen leave for the front again by truck and on foot while this statement appears in superimposition: 'With such men Spain cannot die. The ideal for which they gave their blood is an ideal of peace. So the kids can grow up happy. For tomorrow's beautiful harvest. Spain with a big heart must live. Spain will live. 54 This

53 See Laukötter, 'Measuring Knowledge and Emotions'. See also Laukötter, 'How Films Entered the Classroom'; Laukötter', 'Politik im Kino'.

54 'Avec de tels hommes. L'Espagne ne peut pas mourir. L'idéal pour lequel ils ont prodigué leur sang est un idéal de PAIX. Pour que leurs enfants grandissent dans la joie. Pour les belles moissons de demain. L'Espagne au grand coeur doit vivre. L'Espagne vivra.' 
astonishing comment on Spain and its big heart anchors Cartier-Bresson's film in the territory of emotions. The narrator of Victoire de la vie aims to create solidarity in addressing the nation's 'big heart' and in linking it to the happiness of the children screened.

A similar linkage is addressed in Anja Laukötter's chapter on the relevance of emotions in the creation of new subjectivities in films for East German youth from the 1960s. Analysing narrative strategies and film techniques, the chapter illustrates how these films encourage young people to navigate puberty by managing their emotions in the right way, all with the aim of defining individuals' position in a socialist society. In drawing on scientific knowledge, these films take on a performative role in mimicking the film's emotional suggestions to reach the ultimate aim of producing young socialist subjects.

In both cases, one might argue, using children as objects of concern functions to symbolize authenticity in these films and, at the same time, creates a perspective on a future with a new and better society. The use and sometimes abuse of child subjects in agitation and documentary films to appeal to the audience emotionally is widespread, from interwar social hygiene films,, 55 to the series of six films the Nazis created to promote the sterilization of the mentally ill ${ }^{6}$ in 1930 s Germany, to British municipal films, ${ }^{57}$ to regular appearances of children in telethons and similar broadcasts.

It is not necessarily the depicted child, but also the conveyed childhood experience that produces audience identification and emotionally captures the spectator. David Cantor's chapter addresses this issue in its analysis of the nearsighted Mr. Magoo, one of the most popular animated figures in the American cinema of the 1950s. Cantor discusses Magoo's resurrection in advertisement in the early 1960 s in order to show how Magoo's fading television career turned him into a market asset that enabled a new film producer to use him to a different end. When Magoo went commercial, health was coupled with other consumption goods that Magoo came to represent. In his health advertisement career, Magoo's 'inverse' body capital-namely, his visual handicap — was made into a comic resource intended to charm spectators into accepting difficult health information. The strategy of convincing people through laughter, light-heartedness, and comic slapstick is based on a protagonist behaving in a childlike manner.

\footnotetext{
55 Vignaux,Jean Benoît-Lévy; Bonah and Laukötter, 'Moving Pictures'; and Bonah and Laukötter, 'Introduction'.

56 Bonah and Lowy, 'La propagande sanitaire'.

57 Lebas, Forgotten Futures.
} 
Playing with emotions to make people do things, trust in something, or overcome (childish) fear points to affinities between childhood and documentary film, where children not only symbolize innocence and hope in the future, but also lend the film authenticity. Cinematic realism depicted the sincere experience of childhood in order to spread messages about eminently political issues and ideas.

Techniques intended to suggest authenticity and reality are central to documentary visual media, which defines itself as something that informs, educates, and entertains; for example, the British Broadcasting Corporation (BBC) and the Office de radiodiffusion television française (ORTF). In his chapter, Timothy M. Boon discusses live, on-location television broadcasts from the 1950s, specifically in medical contexts. A new form of media that purported to give viewers a look at unmediated reality, Boon analyses how the camera and broadcast techniques used forced doctors and patients to 'play themselves', since, after all, cameras had to be set up and could not be hardwired into the doctors' eyes, cuts had to be made, etc. He details the grammars of authenticity that gave live, on-location TV the veneer of taking place in the here and now. Among the audiovisual techniques that sought to lend authenticity to film was the inclusion of children. After all, children do not play themselves, they simply play, whether they are in front of a camera or not. Boon analyses the live medical television show Your Life in Their Hands to reveal a different technique. The show purported to offer insight into issues concerning professional confidentiality and the sacredness of the doctor-patient relationship, all the while increasing its entertainment appeal by allowing people the illusion of watching something that was truly taking place combined with the thrill of peeping into events of a confidential, intimate nature. At the same time, live broadcasts outside ultimately constructed what was perceived as the individual's reality. 'Outside' meant filming at the real location; 'live' implied that television was broadcasting as things were happening. However, what was being done was enacted, since agents had to wait for the cameras and their teams to be ready. Thus, cameras did not just simply record what viewers ultimately came to perceive as live and on-site.

In comparing a World Health Organization (WHO) film on infectious diseases from 1948 with contemporary WHO videos and conspiracy videos on the Zika virus from social media, Kirsten Ostherr researches the challenges posed by the multiplication of different visual media, the rapid speed that has closed the gap between the moment of broadcast and the circulation of images, the practices of private archiving that elide established archival practices, and the issues involved when visual 
communication on social networks precedes state public-health intervention. While, in 1948, WHO films were produced in a top-down fashion, the analysis of social media from the early 2000 s and their more horizontal structure indicates an erosion of the control and power of key national and international organizations. Taking a different approach to that of Zoë Druick and Jean-Paul Gaudiellière, Ostherr deploys a global perspective and addresses new questions on new hierarchies and authority of knowledge, the social implications of access and use of information, and its datafication.

\section{Organization of the Book}

Body, Capital, and Screens: Visual Media and the Healthy Self in the 2oth Century is a series of in-depth case studies at the intersection of film and media studies and the social and cultural history of the body. It investigates relationships between film, television, private and public actors of the health sector, and economic development. Our book brings together new research from Europe and North America. Our outlook is international, covering France, Britain, Germany and the German Democratic Republic (GDR), the United States, and global institutions. It discusses key actors and the moving images that depict them in the mass-media society of the 2oth century and its neoliberal market features.

In order to underscore the central status of films, each chapter of this book starts and closes with a vignette from a film emblematic of the chapter's specific thematic focus. The chapters are not limited to one film, but instead use the selected film to develop an argument on the specific aspect of body capital explored in depth throughout the chapter using other visual material.

We sought to include chapters that interact with one another and have tried to indicate here some of their interconnections. We hope that the reader identifies more overlaps and communication between the articles while reading.

In a sense, our approach adheres to the most accepted in visual culture studies, analysing the social construction of the visible and the visible construction of the social. The new element in our work is the connection we establish with bodies and capital and the significance we attribute to visual media in this relationship, a significance that has held for a century's worth of utility media culture. Accordingly, we have arranged the chapters in line with three different aspects of body capital: grammars of film/ television and body capital, which stresses structural elements and different 
approaches to analysing these media; interiorized body capital, which relates to different bodily dimensions of capital, embodiment, and their normative implications; and hegemonies of body capital, which analyses the social construction of bodies and hierarchies. The book desires to provoke further discussions and explorations with the reader about the role of body capital in our visual world.

\section{Works Cited}

\section{Films, Television Programmes, and Recordings}

Children in Need, BBC, 1980-.

La Marseillaise, directed by Jean Renoir, Popular Front, 1937 (unfinished).

Victoire de la vie, directed by Henri Cartier-Bresson, Frontier Films for the Centrale

Sanitaire Internationale, 1937.

Wege zu Kraft und Schönheit, directed by Wilhelm Prager, UFA, 1924/1925.

Your Life in Their Hands, BBC, 1958-1964, 1980-1986.

\section{Books and Articles}

Acland, Charles R., and Haidee Wasson, eds., Useful Cinema (Durham, NC: Duke University Press, 2011).

Amad, Paula, Counter-Archive: Film, the Everyday, and Albert Kahn's Archives de la Planète (New York: Columbia University Press, 2010).

Assouline, Pierre, Henri Cartier-Bresson: L'oeil du siècle (Paris: Gallimard, 2001).

Bänziger, Peter-Paul, and Mischa Suter, eds., Histories of Productivity: Genealogical Perspectives on the Body and Modern Economy (New York: Routledge, 2017). Baudrillard, Jean, The Consumer Society: Myths and Structures (London: Sage, 1998). Becker, Gary S., 'Investment in Human Capital: A Theoretical Analysis', Journal of Political Economy, 70, 5.2 (1962), pp. 9-49, https://www.jstor.org/stable/1829103. Berghoff, Hartmut, and Jakob Vogel, eds., Wirtschaftsgeschichte als Kulturgeschichte: Dimensionen eines Perspektivenwechsels (Frankfurt am Main: Campus, 2004). Bernays, Edward L., Propaganda (New York: Horace Liveright, 1928). Berridge, Virgina, and Kelly Loughlin, Medicine, the Market and the Mass Media: Producing Health in the Twentieth Century (London: Routledge, 2005).

Bonah, Christian, 'In the Service of Industry and Human Health: The Bayer Corporation, Industrial Film, and Promotional Propaganda, 1934-42', in Health Education Films in the Twentieth Century, ed. by Christian Bonah, David Cantor, and Anja Laukötter (Rochester: University of Rochester Press, 2018), pp. 85-142. 
Bonah, Christian, David Cantor, and Anja Laukötter, eds., Health Education Films in the Twentieth Century (Rochester: University of Rochester Press, 2018).

Bonah, Christian, and Anja Laukötter, 'Moving Pictures and Medicine in the First Half of the 2oth Century: Some Notes on International Historical Developments and the Potential of Medical Film Research', Gesnerus, 66, 1 (2009), pp. 121-146.

Bonah, Christian, and Anja Laukötter, 'Introduction: Screening Diseases: Films on Sex Hygiene in Germany and France in the First Half of the 2oth Century', Gesnerus, 72, 1 (2015), pp. 5-14.

Bonah, Christian, and Vincent Lowy, 'La propagande sanitaire par le film documentaire en France et en Allemagne: Réflexions à partir de deux exemples du milieu des années 1930: L'œuvre Grancher et Erbkrank', in Nazisme, science et médecine, ed. by Christian Bonah, Anne Danion-Grilliat, Josiane Olff-Nathan, and Norbert Schappacher (Paris: Glyphe, 2006), pp. 167-192.

Boon, Timothy, Films of Fact: A History of Science in Documentary Films and Television (London: Wallflower, 2008).

Boon, Timothy, 'Medical Films and Television: Alternative Paths to the Cultures of Biomedicine', in The Oxford Handbook of the History of Medicine, ed. by Mark Jackson (Oxford: Oxford University Press, 2011), pp. 617-633.

Bourdieu, Pierre, Esquisse d'une théorie de la pratique: Précédé de trois études d'ethnologie kabyle (Geneva: Droz, 1972) [English translation: Outline of a Theory of Practice, trans. by Richard Nice (Cambridge: Cambridge University Press, 1977)].

Bourdieu, Pierre, La distinction: Critique sociale du jugement (Paris: Éditions de Minuit, 1979) [English translation: Distinction: A Social Critique of the Judgment of Taste, trans. by Richard Nice (Cambridge, MA: Harvard University Press, 1984).

Bourdieu, Pierre, 'The Forms of Capital', in Handbook of Theory and Research for the Sociology of Education, ed. by John G. Richardson (New York: Greenwood, 1986), pp. 46-58.

Bourdieu, Pierre, 'Les trois états du capital culturel', Actes de la recherche en sciences sociales, $30 \overrightarrow{0}$ (November 1979), pp. 3-6, doi:10.3406/arss.1979.2654.

Bourdieu, Pierre, 'Zur Genese der Begriffe Habitus und Feld', in Schriften zu Politik und Kultur, vol. 2: Der Tote packt den Lebenden, ed. by Margareta Steinrücke, trans. by Jürgen Bolder (Hamburg: VSA-Verlag, 1997), pp. 59-78.

Bourdieu, Pierre, and Jean-Claude Passeron, La reproduction: Éléments d'une théorie du système d'enseignement (Paris: Éditions de Minuit, 1970) [English translation: Reproduction in Education, Society and Culture, trans. by Richard Nice (London: Sage, 1977)].

Bourdieu, Pierre, and Loïc J. D. Wacquant, Réponses: Pour une anthropologie réflexive (Paris: Seuil, 1992).

Bourdon, Jérôme, Histoire de la télévision sous de Gaulle, new ed. (Paris: Presses des MinesParistech, 2014). 
Brunnett, Regina, Die Hegemonie symbolischer Gesundheit: Eine Studie zum Mehrwert von Gesundheit im Postfordismus (Bielefeld: transcript, 2009).

Budde, Gunilla, ed., Kapitalismus: Historische Annäherungen (Göttingen: Vandenhoeck \& Ruprecht, 2011).

Cartwright, Lisa, Screening the Body: Tracing Medicine's Visual Culture (Minneapolis: University of Minnesota Press, 1995).

Curtis, Scott, The Shape of Spectatorship: Art, Science, and Early Cinema in Germany (New York: Columbia University Press, 2015).

Daston, Lorraine, and Peter Galison, Objectivity (New York: Zone Books, 2007).

Delavaud, Gilles, and Denis Maréchal, Télévision:Le moment expérimental (Rennes: Apogée, 2011).

Donauer, Sabine, 'Emotions at Work-Working on Emotions: The Production of Economic Selves in Twentieth-Century Germany' ( $\mathrm{PhD}$ thesis, Freie Universität Berlin, 2013).

Ebbinghaus, Bernhard, and Philipp Manow, eds., Comparing Welfare Capitalism: Social Policy and Political Economy in Europe, Japan and the USA (London: Routledge, 2001).

Eitler, Pascal, and Monique Scheer, 'Emotionengeschichte als Körpergeschichte: Eine heuristische Perspektive auf religiöse Konversionen im 19. und 20 Jahrhundert', Geschichte und Gesellschaft, 35, 2 (2009), pp. 282-313, doi: 10.13109/ gege.2009.35.2.282.

Elsaesser, Thomas, 'Propagating Modernity: German Documentaries from the 1930s: Information, Instruction and Indoctrination', in The Oxford Handbook of Propaganda Studies, ed. by Jonathan Auerbach and Russ Castronovo (Oxford: Oxford University Press, 2013), pp. 237-26o, doi:10.1093/oxfordhb/9780199764419.013.013. Forster, Ralf, 'Mitten hinein ins Jugendleben: Die Amateurfilme von Bernd Maywald (1955-1967)', Filmblatt, 21, 60 (2016), pp. 73-84.

Foucault, Michel, Le gouvernement de soi et des autres, 2 vols. (Paris: Seuil, 2008-2009).

Friedman Lester D., ed., Cultural Sutures: Medicine and Media (Durham, NC: Duke University Press, 2004).

Fröhlich, Gerhard, 'Habitus und Hexis: Die Einverleibung der Praxisstrukturen bei Pierre Bourdieu', in Grenzenlose Gesellschaft?, vol. 2, part 2:Ad-hoc-Gruppen, Foren, ed. by Claudia Honegger and Hermann Schwengel (Opladen: Leske + Budrich, 1999), pp. 100-102.

Gaycken, Oliver, Devices of Curiosity: Early Cinema and Popular Science (Oxford: Oxford University Press, 2015).

Greene, Jeremy A., Flurin Condrau, and Elizabeth Siegel Watkins, eds., Therapeutic Revolutions: Pharmaceuticals and Social Change in the Twentieth Century (Chicago: University of Chicago Press, 2016). 
Grossman, Michael, 'On the Concept of Health Capital and the Demand for Health', Journal of Political Economy, 80, 2 (1972), pp. 223-255.

Gumbert, Heather L., Envisioning Socialism: Television and the Cold War in the German Democratic Republic (Ann Arbor: University of Michigan Press, 2014). Hagener, Malte, Vinzenz Hediger, and Alena Strohmaier, eds., The State of PostCinema: Tracing the Moving Image in the Age of Digital Dissemination (London: Palgrave Macmillan, 2016).

Hakim, Catherine, Erotic Capital: The Power of Attraction in the Boardroom and the Bedroom (New York: Basic Books, 2011).

Harper, Graeme, and Andrew Moor, eds., Signs of Life:Medicine and Cinema (London: Wallflower Press, 2005).

Hediger, Vinzenz, Florian Hoof, and Yvonne Zimmermann, eds., Films That Work Harder: The Circulations of Industrial Cinema (Amsterdam: Amsterdam University Press, forthcoming).

Hediger, Vinzenz, and Patrick Vonderau, eds., Films that Work: Industrial Film and the Productivity of Media (Amsterdam: Amsterdam University Press, 2009).

Illouz, Eva, Cold Intimacies: The Making of Emotional Capitalism (Cambridge: Polity Press, 2007).

Kocka, Jürgen, and Marcel van der Linden, eds., Capitalism: The Reemergence of a Historical Concept (London: Bloomsbury, 2016).

Lafon, Benoît, Histoire de la télévision régionale: De la RTF à la 3, 1950-2012 (Brysur-Marne: INA, 2012).

Laukötter, Anja, 'How Films Entered the Classroom: The Sciences and the Emotional Education of Youth through Health Education Films in the United States and Germany, 1910-30', Osiris, 31, 1 (2016), pp. 181-200.

Laukötter, Anja, 'Measuring Knowledge and Emotions: Audience Research in Educational Films at the Beginning of the Twentieth Century', in Health Education Films in the Twentieth Century, ed. by Christian Bonah, David Cantor, and Anja Laukötter (Rochester: University of Rochester Press, 2018), pp. 305-325.

Laukötter, Anja, 'Politik im Kino: Eine Emotions- und Wissenschaftsgeschichte des Sexualaufklärungsfilms im 20. Jahrhundert' (Habilitation thesis, Humboldt Universität zu Berlin, 2018).

Lebas, Elizabeth, Forgotten Futures: British Municipal Cinema 1920-1980 (London: Black Dog, 2011).

Lengwiler, Martin, and Jeanette Madarász, eds., Das präventive Selbst: Eine Kulturgeschichte moderner Gesundheitspolitik (Bielefeld: Transcript, 2010).

Lévy, Marie-Françoise, Regards de la télévision française sur la famille: 105 émissions sélectionnées à travers les archives 1956-1986 (Paris: IDEF, 1987). 
Lippmann, Walter, Public Opinion (New York: Harcourt, Brace and Co., 1922).

Luthans, Fred, Carolyn M. Youssef, and Bruce J. Avolio, Psychological Capital: Developing the Human Competitive Edge (Oxford: Oxford University Press, 2006).

Mattl, Siegfried, Carina Lesky, Vrääth Öhner, and Ingo Zechner, eds., Abenteuer Alltag: Zur Archäologie des Amateurfilms (Vienna: SYNEMA, 2015).

Mitchell, W. J. T., Picture Theory: Essays on Verbal and Visual Representation (Chicago: University of Chicago Press, 1994).

Mitchell, W. J. T., 'What Do Pictures Really Want?', October, 77 (Summer 1996), pp. 71-82, doi:10.2307/77896o.

Mitchell, W. J. T., What Do Pictures Want? The Lives and Loves of Images (Chicago: University of Chicago Press, 2005).

Mitman, Gregg, and Kelley Wilder, Documenting the World: Film, Photography, and the Scientific Record (Chicago: University of Chicago Press, 2016).

Mitman, Gregg, and Kelley Wilder, 'Introduction', in Documenting the World:Film, Photography, and the Scientific Record, ed. by Gregg Mitman and Kelley Wilder (Chicago: University of Chicago Press, 2016), pp.1-22.

Neveu, Érik, 'Les sciences sociales doivent-elles accumuler les capitaux? À propos de Catherine Hakim, Erotic Capital, et de quelques marcottages intempestifs de la notion de capital', Revue française de sciences politiques, 63, 2 (2013), pp. 337-358, http://www.jstor.org/stable/43124237.

Odin, Roger, ed., Le film de famille: Usage privé, usage public (Paris: Méridiens Klincksieck, 1995).

Orgeron, Devin, Marsha Orgeron, and Dan Streible, eds., Learning with the Lights Off: Educational Film in the United States (New York: Oxford University Press, 2012).

Ory, Pascal, La Belle Illusion: Culture et politique sous le signe du Front Populaire, 1935-1938 (Paris: Plon, 1994).

Ostherr, Kirsten, Medical Visions: Producing the Patient through Film, Television, and Imaging Technologies (Oxford: Oxford University Press, 2013).

Poels, Géraldine, Les trente glorieuses du téléspectateur: Une histoire de la réception télévisuelle des années 1950 aux années 1980 (Bry-sur-Marne: INA, 2015).

Powell, Larson, and Robert Shandley, eds., German Television: Historical and Theoretical Approaches (New York: Berghahn, 2016).

Rabeharisoa, Vololona, and Michel Callon, Le pouvoir des malades: L'Association française contre les myopathies et la recherche (Paris: Les presses de l'ecole des mines, 1999).

Rabinbach, Anson, The Human Motor: Energy, Fatigue, and the Origins of Modernity (New York: Basic Books, 1990). 
Reagan, Leslie J., Nancy Tomes, and Paula A. Treichler, Medicine's Moving Pictures: Medicine, Health, and Bodies in American Film and Television (Rochester: University of Rochester Press, 2007).

Reckwitz, Andreas, 'Habitus oder Subjektivierung? Subjektanalyse nach Bourdieu und Foucault', in Pierre Bourdieu und die Kulturwissenschaften: Zur Aktualität eines undisziplinierten Denkens, ed. by Daniel Šuber, Hilmar Schäfer, and Sophia Prinz (Konstanz: UVK, 2011), pp. 41-62.

Reckwitz, Andreas, 'Practices and their Affects', in The Nexus of Practices: Connections, Constellations, Practitioners, ed. by Allison Hui, Theordore R. Schatzki, and Elizabeth Shove (London: Routledge, 2017), pp. 114-125.

Reinecke, Christiane, 'Der (damalige) Geschmack der Bourgeoisie: Eine historische Re-Lektüre von Pierre Bourdieus “Die feinen Unterschiede” (1979)', Zeithistorische Forschungen/Studies in Contemporary History, 14, 2 (2017), pp. 376-383, http://www.zeithistorische-forschungen.de/2-2017/id=5499, accessed 20 September 2018.

Sauvage, Monique, and Isabelle Veyrat-Masson, Histoire de la télévision française: De 1935à nos jours (Paris: Nouveau Monde, 2012).

Scheer, Monique, 'Are Emotions a Kind of Practice (and Is That What Makes them Have a History)? A Bourdieuian Approach to Understanding Emotion', History and Theory, 51, 2 (May 2012), pp. 193-220, https://www.jstor.org/stable/23277639.

Scheper-Hughes, Nancy, and Loïc Wacquant, eds., Commodifying Bodies (London: Sage, 2002).

Shilling, Chris, The Body and Social Theory, 2nd ed. (London: Sage, 2003).

Soulages, Jean-Claude, Les rhétoriques télévisuelles: Le formatage du réel. (Brussels/ Paris: De Boeck Université/INA [Médias Recherches], 2007).

Strauven, Wanda (ed.), The Cinema of Attractions Reloaded (Amsterdam: Amsterdam University Press, 2006).

Thomson, Kevin, Emotional Capital: Maximising the Intangible Assets at the Heart of Brand and Business Success (Oxford: Capstone, 2000).

Vignaux, Valérie, Jean Benoît-Lévy ou le corps comme utopie: Une histoire du cinema èducateur dans l'entre-deux-guerres en France (Paris: AFRHC 2007).

Weehuizen, Rifka Maria, 'Mental Capital: The Economic Significance of Mental Health' (PhD thesis, Universitaire Pers Maastricht, 2008).

Zimmermann, Patricia R., Reel Families: A Social History of Amateur Film (Bloomington: Indiana University Press, 1995).

Zimmermann, Peter, ed., Geschichte des dokumentarischen Films in Deutschland, 3 vols. (Stuttgart: Reclam, 2005).

Zimmermann, Yvonne (ed.), Schaufenster Schweiz. Dokumentarische Gebrauchsfilme 1896-1964 (Zurich: Limmat Verlag, 2011). 


\section{About the Authors}

Christian Bonah, MD, PhD, is professor for the history of medical and health sciences at the University Strasbourg, member of its Institute of Advanced Studies and principal investigator of the ERC Advanced grant BodyCapital. He works on comparative, social, and material history of health, health products and services, and bodies especially in connection with media and law.

Contact details: bonah@unistra.fr

PD Dr. Anja Laukötter is a historian of nineteenth- and twentieth-century European history working in the field of social and cultural history and history of science. She is a researcher at the Center for the History of Emotions at the Max Planck Institute for Human Development and Co-principal investigator of the ERC Advanced grant BodyCapital. Besides other, the main field of her research is the transnational/global history of media, the history of emotions and the history of psychology and pedagogy.

Contact details: laukoetter@mpib-berlin.mpg.de 
This content downloaded from 141.14.156.11 on Mon, 10 Aug 2020 12:11:40 UTC All use subject to https://about.jstor.org/terms 